\title{
Phytogenic as feed additive for suckling dairy calves' has a beneficial effect on animal health and performance
}

\author{
ANDREIA VOLPATO ${ }^{1}$, REGIANE B. CRECENCIO ${ }^{1}$, THAINÃ TOMASI ${ }^{2}$, GABRIELA M. GALLI ${ }^{1}$, \\ LUIZ GUSTAVO GRISS ${ }^{2}$, ANIÉLEN D. DA SILVA ${ }^{3}$, MARIA ROSA C. SCHETINGER ${ }^{3}$, ANA LUIZA B. \\ SCHOGOR $^{1,2}$, MATHEUS D. BALDISSERA ${ }^{4}$, LENITA M. STEFANI ${ }^{1,2}$ and ALEKSANDRO S. DA SILVA S $^{1,2}$ \\ ${ }^{1}$ Programa de Pós-Graduação em Zootecnia, Universidade do Estado de Santa Catarina/UDESC, \\ Rua Beloni Trombeta Zanin, 680E, Santo Antônio, 89815-630 Chapecó, SC, Brazil \\ ${ }^{2}$ Departamento de Zootecnia/UDESC, Rua Beloni Trombeta Zanin, 680E, Santo Antônio, 89814-630 Chapecó, SC, Brazil \\ ${ }^{3}$ Departamento de Bioquímica e Biologia Molecular, Universidade Federal de Santa Maria/ \\ UFSM, Av. Roraima, 1000, 97105-900 Santa Maria, RS, Brazil \\ ${ }^{4}$ Departamento de Microbiologia e Parasitologia, Universidade Federeal de Santa \\ Maria, Av. Roraima, 1000, 97105-900 Santa Maria, RS, Brazil
}

Manuscript received on July 21, 2018; accepted for publication on October 23, 2018

\begin{abstract}
How to cite: VOLPATO A ET AL. 2019. Phytogenic as feed additive for suckling dairy calves' has a beneficial effect on animal health and performance. An Acad Bras Cienc 91: e20180747. DOI. 10.1590/0001-3765201920180747.

Abstract: The aim of this study was to evaluate whether the use phytogenic as feed additive of Holstein calves could exert beneficial effects on animal health and performance. Thirty newborn calves were randomly divided into two groups (control and treated), and the treated consisted of $10 \mathrm{~g}$ of the phytogenic product diluted in milk once a day for 30 days. Blood and fecal samples were collected, and fecal score was performed daily in order to determine the occurrence of diarrhea. Treated calves showed higher hematocrit on days 45 and 60 of life. Serum levels of urea, total proteins, globulins and glucose were lower in the treated group on day 60 of life, while triglycerides were lower on days 15 and 60 of life. Serum glutathione S-transferase activity was higher in treated animals on day 60 of life. Fecal bacterial count was lower in treated animals on days 30 and 60 of life. The weight gain was higher in treated animals on days 60 and 210 of life. Based on these results, it is possible to conclude that the addition of phytogenic as feed additive for calves was able to minimize fecal bacterial infections and to increase body weight gain.
\end{abstract}

Key words: Feed, metabolism, calves, oils, nutrition, animal health.

\section{INTRODUCTION}

Essential oils are secondary metabolic of plants used as an interesting alternative to improve animal production (Benchaar et al. 2008, Chouhan et al. 2017) due to their antibacterial, antifungal, anticoccidial and antioxidant properties (Miguel

Correspondence to: Aleksandro Schafer da Silva

E-mail: aleksandro_ss@yahoo.com.br

ORCid: https://orcid.org/0000-0002-9860-1933
2010, Lee et al. 2004, Kalemba and Kunicka 2003). Some essential oils, such as Melaleuca alternifolia, have potent antibacterial effects against Escherichia coli via the denaturation of membrane proteins, which leads to the rupture of the external membrane, respiratory inhibition, and therefore, cell death (Kalemba and Kunicka 2003). However, essential oils are composed by different molecules derived from terpenoids or phenylpropanoids (Simões 1999). As an example, oregano essential 
oil is composed mainly by carvacrol (80\%), a monoterpene with antioxidant and antibacterial properties (Jayakumar et al. 2012), as observed for cinnamaldehyde (Helander et al. 1998, Barnwal et al. 2018).

Essential or their compounds may be used as feed additives for dairy calves, these ingredients give rise to the products known as phytogenic. Newborn animals are highly susceptible to infections, mainly by gastrointestinal infections caused by bacteria and protozoans, which cause diarrhea, and consequently, economic loss (Wattiaux 2012). In this sense, the elimination of pathogenic bacteria, the reduction of diarrhea and the improvement of the antioxidant system may contribute to enhance animal health and growth rates, promoting earlier physical and sexual maturity. Therefore, the aim of this study was to evaluate whether the addition of phytogenic product as feed additive exerts beneficial effects on calves's health, as well as in the prevention of protozoans or bacterial infections, and consequently, reduction of the incidence of diarrhea and improvement of early life development.

\section{MATERIALS AND METHODS}

\section{ETHICS COMMITTEE}

This study was approved by the Ethical and Animal Welfare Committee of the Universidade do Estado de Santa Catarina (UDESC) under protocol number 4964301116.

\section{PHYTOGENIC PRODUCT}

The phytogenic product used in this study is based on components of the following essential oils as carvacrol, cinnamaldehyde, eucalypt aroma and paprika oleoresin (Activo Calf ${ }^{\circledR}$ ).

\section{ANIMALS, EXPERIMENTAL DESIGN AND DIETS}

This study was conducted in a commercial dairy farm located in Xanxerê city (Santa Catarina,
Brazil) selected due to its optimal facilities and management, despite high sanitary challenge and animal mortality (neonatal mortality of approximately $25 \%$.), i.e., the presence of preventive measures was unable to prevent the occurrence of diarrhea and pneumonia. Thirty newborn calves (Holstein with average weight of $42.04 \pm 3.50 \mathrm{~kg}$ ) were used as the experimental model. It is important to emphasize that animals were monitored until weaning, which occurred on day 60 of life. Newborn calves were housed in individual stalls and received two liters of colostrum (quality evaluated using the refractometer type Brix, considering a limit of $21 \%$, i.e., $>50 \mathrm{mg}$ of Immunoglobulins $/ \mathrm{mL}$ ) up to the first six hours after birth. In addition, the animals received three liters of milk twice a day, with access to concentrate and water ad libitum. With $15 \pm 3$ days of life, the calves were grouped in collective stalls with the capacity of 15 animals, with automatic milk feeding (6 liters per day), concentrate, Tifton 85 hay $(10.7 \%$ crude protein) and water ad libitum. The nutritional and chemical composition of the concentrate are shown in Table I. The concentrate was produced in the farm and it was mainly composed of corn bran and soybean meal.

The calves were randomly divided into two groups (control and oil-treated) of 15 animals each. Treated animals received $10 \mathrm{~g}$ of the product diluted in milk from birth up to 30 days of life twice a day via bottle.

\section{DIARRHEA INCIDENCE AND BODY WEIGHT}

The occurrence of diahrrea was observed daily following the methodology described by Larson et al. (1977), which is based on fecal score and fluidity: (1) normal and solid; (2) pasty but with health aspect; (3) aqueous consistency and (4) fluid consistency.

The body weight was measured through the correlation of the thoracic perimeter using a 
TABLE I

Nutritional and chemical composition of the concentrate.

\begin{tabular}{cc}
\hline Ingredients & Quantity (\%) \\
\hline Corn bran (\% DM*) & 45.0 \\
Soybean meal (\% DM) & 33.0 \\
Soybean hull (\% DM) & 16.0 \\
Premix (\% DM) & 6.0 \\
\hline Chemical composition & Quantity \\
\hline DM (kg) & 500 \\
CP (\% DM) & 22.6 \\
Ether extract (\% DM) & 2.9 \\
NDF (\% DM) & 188.4 \\
ADF (\% DM) & 119.7 \\
\hline
\end{tabular}

* Dry matter (DM), crude protein (CP), NDF (neutral detergent fiber), ADF (acid detergent fiber). ' ${ }^{1}$ Premix composition: calcium (135-165 g/ kg), phosphorus (70 g/ $/ \mathrm{kg})$, sulfur $(25 \mathrm{~g} /$ $\mathrm{kg})$, magnesium $(25 \mathrm{~g} / \mathrm{kg})$, potassium $(30 \mathrm{~g} / \mathrm{kg})$, cobaltous (4.3 mg/kg), copper (425 mg/kg), chrome (25 mg/kg), iron $(1750 \mathrm{mg} / \mathrm{kg})$, iodine $(11 \mathrm{mg} / \mathrm{kg})$, manganese $(1700 \mathrm{mg} / \mathrm{kg})$, selenium $(13 \mathrm{mg} / \mathrm{kg})$, zinc $(1700 \mathrm{mg} / \mathrm{kg})$, biotin $(1.5 \mathrm{mg} / \mathrm{kg})$, vitamin A (350000 UI/kg), vitamin D3 (25000 UI/ $\mathrm{kg})$, vitamin E (2000 UI/kg), pantothenic acid (126 mg/kg), vitamin B1 $(50 \mathrm{mg} / \mathrm{kg})$, vitamin B6 (60 mg/kg), vitamin B12 (1.11 mg/ $\mathrm{kg})$, choline $(9000 \mathrm{mg} / \mathrm{kg})$, niacin $(247.50 \mathrm{mg} / \mathrm{kg})$, riboflavin (50 mg/kg), vitamin C (6000 mg/kg), vitamin K (20 mg/kg), D-limonene $(3300 \mathrm{mg} / \mathrm{kg})$, Saccharomyces cerevisiae $(0.75 \mathrm{x}$ $\left.10^{9} \mathrm{UFC} / \mathrm{kg}\right)$, fluorine $(700 \mathrm{mg} / \mathrm{kg})$ and bicarbonate $(135 \mathrm{~g} / \mathrm{kg})$.

measure tape (Heinrichs and Hargrove 1987) on days 1 and 60 of life (experimental period) and on day 210 of life (growth period).

\section{SAMPLE COLLECTION}

The first blood collection occurred in the first 24 hours of life, after colostrum consumption (day $1)$, while the other samplings (blood and feces) were performed on days 15, 30, 45 and 60 of life. Blood collection was performed directly from the jugular vein using tubes containing EDTA $(10 \%)$ for hematocrit and into tubes without this anticoagulant. Samples collected into tubes without anticoagulant were centrifuged at $7000 \mathrm{rpm}$ during
10 min to obtain sera which were transferred to microtubes and stored at $-20{ }^{\circ} \mathrm{C}$ until utilization.

Fecal samples were obtained directly from the rectal ampule, which were stored at $8{ }^{\circ} \mathrm{C}$ until utilization. One portion of each fecal sample was used for bacterial counts, and the other portion for protozoan research.

\section{HEMATOCRIT}

The hematocrit was performed up to $2 \mathrm{~h}$ after blood collection. The microhematocrit was performed using capillaries tubes after a centrifugation at $10000 \mathrm{rpm}$ during $3 \mathrm{~min}$. The percentage of erythrocytes was evaluated using a reading card, as preconized by Feldman et al. (2000).

\section{SERUM BIOCHEMISTRY}

Seric levels of total protein, albumin, urea, glucose, cholesterol and triglycerides were measured through the semi-automated analyzer BioPlus $2000^{\circledR}$ using commercial kits (Analisa Gold ${ }^{\circledR}$ ) following manufacturer's recommendations. The globulin levels were obtained by mathematic calculi (total protein - albumin).

\section{SERUM ANTIOXIDANT/OXIDANT STATUS}

Serum lipid peroxidation was determined according to the methodology described by Jentzsch et al. (1996), which measures the levels of malondialdehyde (MDA) by thiobarbituric acid reactive substance (TBARS), and results are expressed as $\mu \mathrm{m} \mathrm{MDA} / \mathrm{mL}$.

The serum ROS levels were quantified by fluorimetric method of diacetate dichlorofluoresce in (DCFH-DCF) (Ali et al. 1992), and the results were expressed as $\mathrm{U} \mathrm{DCF} / \mathrm{mL}$

The activity of the antioxidant enzyme glutathione S-transferase (GST) was analyzed in serum using the method described by Habig et al. (1974), and the results were expressed as $\mu \mathrm{molCdnb} / \mathrm{min} / \mathrm{mL}$. 


\section{TOTAL BACTERIAL COUNT}

A portion of fresh fecal sample was used to perform the total bacterial count. For this, 1 gram of feces was diluted in $9 \mathrm{~mL}$ of buffered peptone water, followed by seven more seriated dilutions. From dilution seven and eight, aliquots of $1 \mathrm{~mL}$ were incubated into total aerobic count plates (3M Petrifilm ${ }^{\circledR}$ Plate). This plate is a system of culture medium ready for use which contains all nutrients of the standard method, as well as an indicator that facilitates colony counting and the results were expressed as $\mathrm{CFU} / \mathrm{g}$ of feces.

\section{PARASITOLOGICAL EXAMINATION}

Parasitological examination was performed to determine the presence of Cryptosporidium spp. and Eimeria spp. oocysts, as well as cysts of Giardia duodenalis. For this, $2 \mathrm{~g}$ of feces were processed using the centrifugal-flotation technique with a hypersaturated sugar solution, according to the methodology described by Monteiro (2010).

\section{STATISTICAL ANALYSIS}

The data from 30 animals were firstly evaluated by descriptive statistics for contingency of information and for further assumptions which are presented as mean and standard deviation. All covariates were tested for normality using the Shapiro-Wilk test (Shapiro-Wilk 1965), and the skewness, kurtosis and homogeneity by the Levene test. The data did not show normal distribution, and were transformed to logarithm and normalized, with the exception of the total bacterial count data. A repeated measure t-test was used to examine differences of the parameters between control and treated groups. All parameters compared mean between groups in the Student's $t$-test (controlling for data dependency due to dependence in time) was used to analyze all parameters at each time period (days 1, 15 and 30, 45 and 60 of the experiment). For total bacterial counts a nonparametric test was used by Kruskal-
Wallis test. The chi-square test was used to verify the occurrence of diarrhea and the presence of parasites (Giardia and Eimeria) between groups. All plots were visualized using the ggplot2 package (Wickham 2009). It was considered significantly different when $\mathrm{P}<0.05$. The statistical process was performed using R-language, v.2.15.1 (R Development Core Team 2012).

\section{RESULTS}

\section{WEIGHT AND WEIGHT GAIN}

No difference was observed between groups regarding "body weight" on days 1 (control: $43 \pm 2.4$; treated: $42 \pm 2.0-\mathrm{P}=0.854$ ), 60 (control: $78 \pm 5.1$; treated: $82 \pm 4.6-\mathrm{P}=0.235)$ and 210 (control: $161 \pm 11.3$; treated: $172 \pm 10.7-\mathrm{P}=0.095$ ) of life. Throughout the time, body weight gain was observed in both groups at three times: 1 to $60 ; 1$ to 210 and 60 to $210(\mathrm{P}<0.05)$.

Higher "weight gain" was observed on days 1 to 60 , and 1 to 210 on treated animals compared to the control group (Figure 1). On day 210 of life, control and treated animals showed a daily weight gain of 569 and $641 \mathrm{~g}$, respectively.

\section{HEMATOCRIT AND SERIC BIOCHEMISTRY}

On days 45 and 60 of life it was observed a significant difference between groups regarding hematocrit

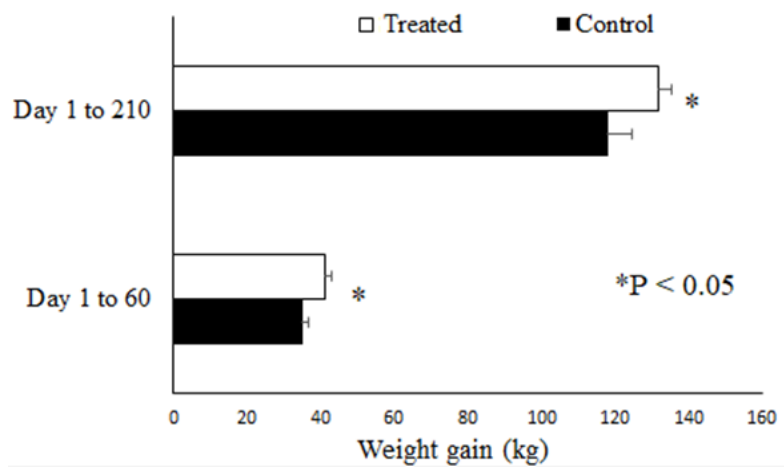

Figure 1 - Weight gain of calves treated with a mixture containing components of essential oils. $* \mathrm{P}<0.05$ indicates significant difference between groups. 
(Table II). Throughout the time, hematocrit increased in the treated group (Table II). The comparison between groups at different times was presented in Table II. The serum levels of urea, total proteins and globulins were lower in the treated group on day 60 of life compared to the control group, while albumin levels were not different (Table II). Throughout the time, the total protein and globulin levels increased in the control group from days 1 to 60 . The serum levels of glucose, triglycerides and cholesterol are shown in the Table II. No difference was observed between groups regarding cholesterol levels in all evaluated moments. On the other hand, serum levels of glucose were lower in treated animals on day 60 of life, while triglycerides levels were lower on days 15 and 60 of life compared to the control group.

In the analysis of results over time (repeated measures), it was also presented in Table II. In the control group, there was an increase over time in the levels of urea, total proteins, albumin and globulins (Table II). Cholesterol levels over time increased in both groups (Table II). However, glucose and triglyceride levels did not differ $(\mathrm{P}>0.05)$ over time in both groups (Table II).

\section{OXIDANTS AND GLUTATHIONE S-TRANSFERASE ACTIVITY}

No difference between groups was observed regarding ROS and TBARS levels. However, the

\section{TABLE II}

Hematocrit (total blood), urea, total proteins, albumin, globulins, glucose, triglycerides and cholesterol in serum of calves not treated (control) and treated with essential oils.

\begin{tabular}{|c|c|c|c|c|}
\hline Variable & Day & Control & Treated & P-value \\
\hline \multirow{5}{*}{ Hematocrit (\%) } & 1 & $28.6 \pm 1.15$ & $29.6 \pm 2.6^{b}$ & 0.870 \\
\hline & 15 & $25.2 \pm 6.70$ & $26.7 \pm 3.0^{\mathrm{b}}$ & 0.972 \\
\hline & 30 & $29.6 \pm 5.90$ & $29.5 \pm 4.0^{\mathrm{ab}}$ & 0.822 \\
\hline & 45 & $30.4 \pm 4.80$ & $35.1 \pm 2.9^{\mathrm{a}}$ & $0.042 *$ \\
\hline & 60 & $30.6 \pm 5.19$ & $35.5 \pm 2.5^{\mathrm{a}}$ & $0.027 *$ \\
\hline P-value & & 0.423 & $\mathrm{0.001}^{\#}$ & \\
\hline \multirow{5}{*}{$\begin{array}{c}\text { Urea } \\
(\mathrm{mg} / \mathrm{dL})\end{array}$} & 1 & $25.5 \pm 8.40^{\mathrm{bc}}$ & $26.2 \pm 7.4$ & 0.742 \\
\hline & 15 & $23.1 \pm 4.00^{\mathrm{c}}$ & $25.8 \pm 10.1$ & 0.650 \\
\hline & 30 & $28.7 \pm 10.6^{\mathrm{ab}}$ & $21.2 \pm 6.6$ & 0.146 \\
\hline & 45 & $37.8 \pm 12.7^{\mathrm{ab}}$ & $27.6 \pm 6.7$ & 0.087 \\
\hline & 60 & $36.10 \pm 6.1^{\mathrm{a}}$ & $24.8 \pm 7.7$ & $0.010 *$ \\
\hline P-value & & $\mathbf{0 . 0 3 5}^{\#}$ & 0.254 & \\
\hline \multirow{5}{*}{ Total proteins $(\mathrm{g} / \mathrm{dL})$} & 1 & $5.60 \pm 1.31^{b}$ & $6.4 \pm 3.1$ & 0.546 \\
\hline & 15 & $7.00 \pm 1.50^{\mathrm{ab}}$ & $5.7 \pm 1.9$ & 0.649 \\
\hline & 30 & $7.22 \pm 2.20^{\mathrm{ab}}$ & $6.11 \pm 1.57$ & 0.334 \\
\hline & 45 & $7.53 \pm 1.58^{\mathrm{a}}$ & $6.2 \pm 1.4$ & 0.092 \\
\hline & 60 & $8.33 \pm 1.68^{\mathrm{a}}$ & $5.97 \pm 1.18$ & 0.001* \\
\hline P-value & & $\mathrm{O.001}^{\#}$ & 0.562 & \\
\hline \multirow{5}{*}{$\begin{array}{l}\text { Albumin } \\
(\mathrm{g} / \mathrm{dL})\end{array}$} & 1 & $2.07 \pm 0.56^{\mathrm{b}}$ & $2.12 \pm 0.88$ & 0.733 \\
\hline & 15 & $2.74 \pm 0.53^{\mathrm{ab}}$ & $2.57 \pm 1.22$ & 0.640 \\
\hline & 30 & $2.78 \pm 0.52^{\mathrm{ab}}$ & $2.71 \pm 0.90$ & 0.970 \\
\hline & 45 & $3.11 \pm 0.48^{\mathrm{a}}$ & $2.65 \pm 1.0$ & 0.270 \\
\hline & 60 & $2.85 \pm 0.60^{\mathrm{a}}$ & $2.46 \pm 0.86$ & 0.481 \\
\hline P-value & & $0.027^{\#}$ & 0.687 & \\
\hline
\end{tabular}


TABLE II (continuation)

\begin{tabular}{|c|c|c|c|c|}
\hline Variable & Day & Control & Treated & P-value \\
\hline \multirow{5}{*}{$\begin{array}{l}\text { Globulins } \\
\text { (g/dL) }\end{array}$} & 1 & $3.60 \pm 1.44^{b}$ & $4.7 \pm 2.68$ & 0.240 \\
\hline & 15 & $4.26 \pm 1.56^{\mathrm{ab}}$ & $3.4 \pm 2.26$ & 0.470 \\
\hline & 30 & $4.63 \pm 1.90^{\mathrm{ab}}$ & $3.98 \pm 1.57$ & 0.554 \\
\hline & 45 & $4.61 \pm 1.94^{\mathrm{ab}}$ & $3.95 \pm 2.2$ & 0.424 \\
\hline & 60 & $5.66 \pm 1.87^{\mathrm{a}}$ & $3.72 \pm 1.1$ & $0.01 *$ \\
\hline P-value & & $\mathrm{0.001}^{\#}$ & 0.085 & \\
\hline \multirow{5}{*}{ Glucose (mg/dL) } & 1 & $90.9 \pm 36.70$ & $105.80 \pm 37.70$ & 0.249 \\
\hline & 15 & $125.3 \pm 60.8$ & $109.60 \pm 31.10$ & 0.462 \\
\hline & 30 & $103.2 \pm 23.60$ & $97.30 \pm 37.00$ & 0.639 \\
\hline & 45 & $99.00 \pm 33.30$ & $95.23 \pm 36.0$ & 0.528 \\
\hline & 60 & $110.7 \pm 34.5$ & $78.07 \pm 15.1$ & $0.038 *$ \\
\hline P-value & & 0.485 & 0.165 & \\
\hline \multirow{5}{*}{ Triglycerides (mg/dL) } & 1 & $35.20 \pm 13.00$ & $34.70 \pm 19.9$ & 0.704 \\
\hline & 15 & $28.60 \pm 12.20$ & $16.40 \pm 5.22$ & $0.044 *$ \\
\hline & 30 & $33.2 \pm 15.70$ & $21.70 \pm 8.24$ & 0.071 \\
\hline & 45 & $35.9 \pm 10.70$ & $27.60 \pm 7.60$ & 0.130 \\
\hline & 60 & $36.0 \pm 6.15$ & $24.80 \pm 7.70$ & $0.029 *$ \\
\hline P-value & & 0.620 & 0.201 & \\
\hline \multirow{5}{*}{ Cholesterol (mg/dL) } & 1 & $21.42 \pm 6.60^{c}$ & $32.50 \pm 14.60^{b}$ & 0.187 \\
\hline & 15 & $51.7 \pm 12.70^{\mathrm{b}}$ & $56.70 \pm 29.30^{\mathrm{ab}}$ & 0.732 \\
\hline & 30 & $72.8 \pm 20.6^{\mathrm{ab}}$ & $62.10 \pm 18.20^{\mathrm{a}}$ & 0.334 \\
\hline & 45 & $79.50 \pm 22.00^{\mathrm{a}}$ & $58.60 \pm 17.60^{\mathrm{a}}$ & 0.199 \\
\hline & 60 & $72.00 \pm 28.8^{\mathrm{ab}}$ & $66.60 \pm 21.40^{\mathrm{a}}$ & 0.527 \\
\hline
\end{tabular}

* $\mathrm{P}<0.05$ in the same line indicates significant difference between groups. ${ }^{\#} \mathrm{P}<0.05$ in the same column shows difference over time in each group, and the differences are represented by different letters and subscripts.

serum GST activity was higher in treated animals on day 60 of life compared to the control group. Throughout time, serum levels of ROS and TBARS reduced in both groups, as well as increased activity of GST in the animals of the treated group (Table III).

\section{FECAL BACTERIAL COUNT}

Fecal bacterial counts were lower in treated animals on days 30 and 60 of life compared to the control group (Figure 2). Throughout time, it was observed a numerical reduction on bacterial counts of both groups. The reduction was significant on days 30 to 45 in the control group $(\mathrm{P}=0.036)$ and on days 45 and 60 in treated animals.

\section{PARASITOLOGICAL EXAMINATION}

No difference was observed between groups regarding the presence of protozoans. However, it was verified that seven control animals and three treated animals were positives for Giardia spp. On day 30, infections caused by Giardia spp. were observed in four animals from the control group, as well as two positive animals for Eimeria spp. In this same period, only two animals were positives for Giardia spp. in the treated group. At 45 days of life, infection by Giardia spp. and Eimeria spp. was observed in 10 animals of each group. On day 60 of life, infections caused by both parasites 


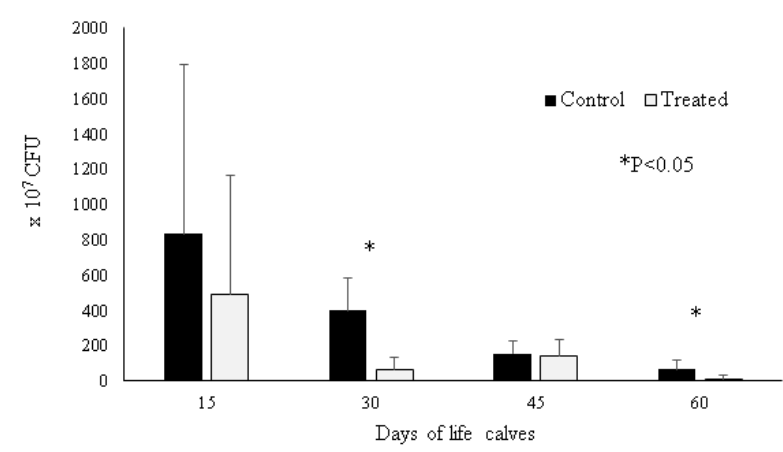

Figure 2 - Total bacterial count in fecal samples of calves treated with a mixture containing components of essential oils. $* \mathrm{P}<0.05$ in the same line indicates significant difference between groups.

remained in the control group ( $\mathrm{n}=7$ animals), while the treated group showed only Eimeria spp. $(\mathrm{n}=3)$.

\section{DIARRHEA INCIDENCE}

No difference was observed between groups regarding the incidence of diarrhea. However, it is important to emphasize that this clinical sign was observed in $73.3 \%$ of control animals and $40 \%$ of treated animals on day 15 of life. On day 30, diarrhea was observed in 1 or 2 animals per group.

\section{DISCUSSION}

Animals treated with phytogenic product obtained higher weight gain, which may be a direct or indirect effect of the treatment. Indirectly, this weight gain may be linked to improved animal health due to the stimulation of the immune and antioxidant systems, as well as in the reduction of fecal bacterial counts. Directly, it may be associated with higher consumption of the concentrate stimulated by the oil product, a fact proved by a positive correlation between weight gain and concentrate levels (Bartle et al. 1994). In this sense, some studies indicated that the use of oregano and/or cinnamon essential oils as additives improve piglets performance (Franz et al. 2010).

Origanum vulgare (oregano) essential oil has the capability to induce a significant increase on
GST activity (Lam and Zheng 1991), in accordance to what was observed in this study. However, this oil has monoterpene carvacrol as its main compound (Jayakumar et al. 2012), which exerts a potent antioxidant effect (Barnwal et al. 2018). Although this treatment caused a stimulation of the antioxidant system, no effects were observed regarding levels of free radicals and lipid peroxidation.

In piglets, the addition of essential oils reduced the occurrence of diarrhea and decreased the number of Escherichia coli in fecal samples (Li et al. 2012). According to the literature, the carvacrol and cinnamaldehyde, which are components of the cinnamon oil, exert an inhibitory effect against $E$. coli and Salmonella Typhimurium (Helander et al. 1998, Friedman et al. 2004), important diarrheic agents. According to Helander et al. (1998), the action mechanism involved in carvacrol against $E$. coli is associated with disintegration of cell membrane and release of organelles in the extracellular medium. In this present study, the animals treated with the commercial product showed lower fecal bacterial counts, which can be related to an antibacterial action of the components present in this product. Even though it was not evaluated in this study, Giannenas et al. (2003) demonstrated that $O$. vulgare essential oil has potent anticoccidial effects in birds experimentally infected by Eimeria tenella. The hematocrit count was higher in treated animals on days 45 and 60 of life, in agreement with Al-Kassie (2009) while studying broilers fed with a diet supplemented with cinnamon oil. On the other hand, this result was not observed in birds (Hashemipour et al. 2013, Saadat Shad et al. 2016) and fish (Ahmadifar et al. 2011, Yilmaz et al. 2015) fed with thymol or carvacrol.

Serum urea, total proteins and globulins levels were lower in treated animals on day 60 of life, as observed by Al-Kassie et al. (2009) in broilers that received cinnamon oil. On the other hand, levels of serum total protein were not influence by the addition of cinnamon oil in the diet of sheep 
TABLE III

Levels of reactive oxygen species (ROS), and thiobarbituric reactive acid substances (TBARS), and gluthatione S-transferase (GST) activity in serum of calves from control and treated groups.

\begin{tabular}{|c|c|c|c|c|}
\hline Variable & Days & Control & Treated & P-value \\
\hline \multirow{5}{*}{$\begin{array}{c}\text { ROS } \\
(\mathrm{U} \mathrm{DCF} / \mathrm{mL})\end{array}$} & 1 & $44.2 \pm 22.9^{a}$ & $57.7 \pm 20.5^{\mathrm{a}}$ & 0.393 \\
\hline & 15 & $31.5 \pm 11.3^{a b}$ & $29.9 \pm 13.1^{\mathrm{ab}}$ & 0.870 \\
\hline & 30 & $28.8 \pm 11.5^{\mathrm{ab}}$ & $25.9 \pm 12.2^{b c}$ & 0.632 \\
\hline & 45 & $20.2 \pm 6.5^{b c}$ & $16.9 \pm 4.1^{\mathrm{c}}$ & 0.155 \\
\hline & 60 & $18.7 \pm 4.9^{c}$ & $18.1 \pm 2.7^{\mathrm{c}}$ & 0.789 \\
\hline P-value & & $\mathrm{O.001}^{\#}$ & $\mathbf{0 . 0 0 1}^{\#}$ & \\
\hline \multirow{5}{*}{$\begin{array}{c}\text { TBARS } \\
(\mu \mathrm{m} \mathrm{MDA} / \mathrm{mL})\end{array}$} & 1 & $4.0 \pm 2.5^{\mathrm{a}}$ & $4.6 \pm 3.2^{\mathrm{a}}$ & 0.840 \\
\hline & 15 & $1.4 \pm 0.4^{\mathrm{b}}$ & $1.3 \pm 0.3^{b}$ & 0.804 \\
\hline & 30 & $1.4 \pm 0.4^{\mathrm{b}}$ & $1.4 \pm 0.4^{\mathrm{b}}$ & 0.974 \\
\hline & 45 & $1.29 \pm 0.4^{\mathrm{b}}$ & $1.3 \pm 0.4^{\mathrm{b}}$ & 0.903 \\
\hline & 60 & $1.4 \pm 0.7^{\mathrm{b}}$ & $1.11 \pm 0.3^{\mathrm{b}}$ & 0.794 \\
\hline P-value & & $0.001^{\#}$ & $\mathbf{0 . 0 0 1}^{\#}$ & \\
\hline \multirow{5}{*}{$\begin{array}{c}\text { GST } \\
(\mu \mathrm{mol} \mathrm{Cdnb} / \mathrm{min} / \mathrm{mL})\end{array}$} & 1 & $16.0 \pm 7.1$ & $15.5 \pm 7.3^{b}$ & 0.740 \\
\hline & 15 & $27.3 \pm 14.9$ & $21.8 \pm 9.8^{\mathrm{ab}}$ & 0.279 \\
\hline & 30 & $17.2 \pm 7.4$ & $21.3 \pm 8.6^{\mathrm{ab}}$ & 0.538 \\
\hline & 45 & $17.6 \pm 7.2$ & $21.5 \pm 4.1^{\mathrm{ab}}$ & 0.431 \\
\hline & 60 & $16.4 \pm 6.7$ & $23.4 \pm 6.08^{\mathrm{a}}$ & $0.040 *$ \\
\hline P-value & & 0.413 & $\mathbf{0 . 0 2 3}^{\#}$ & \\
\hline
\end{tabular}

${ }^{*} \mathrm{P}<0.05$ in the same line indicates significant difference between groups. ${ }^{\#} \mathrm{P}<0.05$ in the same column shows difference over time in each group, and the differences are represented by different letters and subscripts.

(Khateri et al. 2017). The serum triglycerides levels were lower in the treated group on days 15 and 60 of life, which disagrees with Saadat Shad et al. (2016), that did not observe differences in birds treatment with carvacrol and thymol.

Serum glucose levels were lower in treated animals on day 60 of life, in disagreement with Santos et al. (2015). According to these authors, serum glucose levels were not affected in calves supplemented with a product based on essential oils. Possibly, the animals from the treated group consumed preferably concentrate, while the control group consumed a liquid diet. According to Quigley and Bernard (1991) and Santos et al. (2015), animals that consume liquid diet showed major concentrations of glucose in comparison to those receiving solid diets, since these animals use fatty acids of short chain as a source of energy.
However, we cannot assure that the essential oils influenced the consumption of concentrate, since animal consumption was not a parameter evaluated in this study.

Based on these evidences, we concluded that the addition of phytogenic product as feed additive of calves was able to minimize bacterial infections and to improve their overall health during breastfeeding, as well as it caused weight gain and enhanced animal performance. Therefore, it can be considered a potential additive to be used in the diet since affected positively the animal growth, as well as exerted antimicrobial and antioxidant effects.

\section{AUTHOR CONTRIBUTIONS}

VOLPATO A and DA SILVA AS contributed to the design and implementation of the research, to the analysis of the results and to 
the writing of the manuscript.SCHOGOR ALB helped in the elaboration of the project and its execution. STEFANI LM supervised the project. CRECENCIO RB assisted with microbiological measurements. TOMASI T, GALLI GM and GRISS LG, assisted with parasitological measurements. BALDISSERA MD assisted with antioxidant and oxidant measurements. DA SILVA $\mathrm{AD}$ and SCHETINGER MRC assisted with blood parameters measurements. All authors discussed the results and contributed to the final manuscript.

\section{REFERENCES}

AHMADIFAR E, FALAHATKAR B AND AKRAMI R. 2011. Effects of dietary thymol-carvacrol on growth performance, hematological parameters and tissue composition of juvenile rainbow trout, Oncorhynchus mykiss. J Appl Ichthyol 27(4): 1057-1060.

AL-KASSIE GAM. 2009. Influence of two plant extracts derived from thyme and cinnamon on broiler performance. Pak Vet J 29: 169-173.

ALI SF, LEBEL CP AND BONDY SC 1992. Reactive oxygen species formation as a biomarker of methylmercury and trimethyltin neurotoxicity. Neurotoxicology 13(3): 63748.

BARNWAL P, VAFA A, AFZAL SM, SHAHID A, HASAN SK, ALPASHREE S AND SULTANA S. 2018. Benzo(a) pyrene induces lung toxicity and inflammation in mice: prevention by carvacrol. Hum Ex Toxicol 37(7): 752-761.

BARTLE SJ, PRESTON RLAND MILLER MF. 1994. Dietary energy sources and density: effects of roughage equivalent, tallow level, and steer type on feedlot performance and carcass characteristics. J Anim Sci 72(8): 1943-1953.

BENCHAAR C, CALSAMIGLIA S, CHAVES AV, FRASER GR, COLOMBATTO D, MCALLISTER TA AND BEAUCHEMIN KA. 2008. A review of plant-derived essential oils in ruminant nutrition and production. Anim Feed Sci Tech 145(1-4): 209-228.

CHOUHAN S, SHARMA K AND GULERIA S. 2017. Antimicrobial Activity of Some Essential Oils-Present Status and Future Perspectives. Medicines 4(3): 58.

FELDMAN BF, ZINKL JG AND JAIN NC. 2000. Schalm's Veterinary Hematology. $5^{\text {th }}$ ed., Philadelphia: Lippincott Williams \& Williams, p. 1120-1124.

FRANZ C, BASER KHC AND WINDISCH W. 2010. Essential oils and aromatic plants in animal feeding - a European perspective. A review. Flavour Fragr Jornal 25: $327-340$
FRIEDMAN M, BUICK R AND ELLIOTT CT. 2004. Antibacterial activities of naturally occurring compounds against antibiotic-resistant Bacillus cereus vegetative cells and spores, Escherichia coli, and Staphylococcus aureus. Journal Food Prot 67(8): 1774-1778.

GIANNENAS I, FLOROU-PANERI P, PAPAZAHARIADOU M, CHRISTAKI E, BOTSOGLOU NA AND SPAIS AB. 2003. Effect of dietary supplementation with oregano essential oil on performance of broilers after experimental infection with Eimeria tenella. Arch Anim Nutr 57: 99106.

HABIG WH, PABST MJ AND JAKOBY WB. 1974. Glutathione S-transferases. The first enzymatic step in mercapturic acid formation. J Biol Chem 249(22): 71307139.

HASHEMIPOUR H, KERMANSHAHI H, GOLIAN A AND VELDKAMP T. 2013. Effect of thymol and carvacrol feed supplementation on performance, antioxidant enzyme activities, fatty acid composition, digestive enzyme activities, and immune response in broiler chickens. Poult Sci 92(8): 2059-2069.

HEINRICHS AJ AND HARGROVE GL. 1987. Standards of weight and height for Holstein heifers. J Dairy Sci 70(3): 653-660.

HELANDER IM, ALAKOMI H, LATVA-KALA K, MATTILA-SANDHOLM T, POL I, SMID EJ, GORRIS LGM AND VON WRIGHT A. 1998. Characterization of the Action of Selected Essential Oil Components on GramNegative Bacteria. J Agric Food Chem 46(9): 3590-3595.

JAYAKUMAR S, MADANKUMAR A, ASOKKUMAR S, RAGHUNANDHAKUMAR S, GOKULA DHAS $\mathrm{K}$, KAMARAJ S, DIVYA MG AND DEVAKI $T$. 2012. Potential preventive effect of carvacrol against diethylnitrosamine-induced hepatocellular carcinoma in rats. Mol Cell Biochem 360(1-2): 51-60.

JENTZSCH AM, BACHMANN H, FÜRST P AND BIESALSKI HK. 1996. Improved analysis of malondialdehyde in human body fluids. Free Rad Biol Med 20(2): 251-256.

KALEMBA D AND KUNICKA A. 2003. Antibacterial and Antifungal Properties of Essential Oils. Curr Med Chem 10: 813-829.

KHATERI N, AZIZI O AND JAHANI-AZIZABADI H. 2017. Effects of a specific blend of essential oils on apparent nutrient digestion, rumen fermentation and rumen microbial populations in sheep fed a 50:50 alfalfa hay:concentrate diet. Asian-Australas J Anim Sci 30(3): 370-378.

LAM LKT AND ZHENG B. 1991. Effects of Essential Oils on Glutathione S-Transferase Activity in Mice. J Agric Food Chem 39(4): 660-662.

LARSON LL, OWEN FG, ALBRIGHT JL, APPLEMAN RD, LAMB RC AND MULLER LD. 1977. Guidelines 
toward more uniformity in measuring and reporting calf experimental data. J Dairy Sci 60(6): 989-991.

LEE KW, EVERTS H AND BEYNEN AC. 2004. Essential oils in broiler nutrition. Int J Poult Sci 3: 738-752.

LI SY, RU YJ, LIU M, XU B, PÉRON A AND SHI XG. 2012. The effect of essential oils on performance, immunity and gut microbial population in weaner pigs. Livest Sci 145: 119-123.

MIGUEL MG. 2010. Antioxidant and anti-inflammatory activities of essential oils: a short review. Molecules 15(12): 9252-9287.

MONTEIRO SC. 2010. Parasitologia na Medicina Veterinária. São Paulo: Roca, 356 p.

QUIGLEY JD AND BERNARD JK. 1992. Effects of nutrient source and time of feeding on changes in blood metabolites in young calves. J Anim Sci 70(5): 1543-1549.

R DEVELOPMENT CORE TEAM. 2012. R: A Language and Environment for Statistical Computing. Vienna: R foundation for Statistical Computing. http://www.Rproject.org/

SAADAT SHAD H, MAZHARI M, ESMAEILIPOUR O AND KHOSRAVINIA H. 2016. Effects of Thymol and Carvacrol on Productive Performance, Antioxidant
Enzyme Activity and Certain Blood Metabolites in Heat Stressed Broilers. Iran J Appl Anim Sci 6(1): 195-202.

SANTOS FHR, DE PAULA MR, LEZIER D, SILVA JT, SANTOS G AND BITTAR CMM. 2015. Essential oils for dairy calves: effects on performance, scours, rumen fermentation and intestinal fauna. Animal 9(6): 958-965.

SHAPIRO SS AND WILK MB. 1965. An analysis of variance test for normality (complete sample). Biometrika, Great Britain 52(3): 591-611.

SIMÕES CMO. 1999. Farmacognosia: da planta ao medicamento, Porto Alegre: Ed. Universidade/UFRGS; Florianópolis: Ed. da UFSC.

WATTIAUX MA. 2012. Essenciais em Gado de LeiteCriação de Novilhas. The Babcock Institute: University of Wisconsin-Madison, p. 121-124.

WICKHAM H. 2009. Elegant Graphics for Data Analysis. Springer, New York, USA.

YILMAZ E, ERGÜN S AND YILMAZ S. 2015. Influence of Carvacrol on the Growth Performance, Hematological, Non-Specific Immune and Serum Biochemistry Parameters in Rainbow Trout (Oncorhynchus mykiss). Food and Nutrition Sciences 6: 523-531. 